\title{
Cancer Prevention Biomarker and Genotyping Shared Resource
}

National Cancer Institute

\section{Source}

National Cancer Institute. Cancer Prevention Biomarker and Genotyping Shared

Resource. NCI Thesaurus. Code C39346.

The Cancer Prevention Biomarker and Genotyping Resource provides Cancer Center investigators with support in genotyping and biomarker assays to evaluate markers of disease susceptibility and therapeutic response including biochemical and immunological assays to detect or quantitate cellular proteins, hormones, or metabolites, polymorphism panels that include genes that are of highest interest in cancer prevention and treatment, i.e., DNA repair, detoxification, immunoregulation and viral clearance, steroidogenesis, cell cycle regulation, and drug metabolism; and appropriate sample collection, storage, and handling for genotyping or biomarker analysis, as well as consultation on testing and markers information. 